\title{
Association of serum calcium and uric acid level with hypertensive disorders of pregnancy [pre eclampsia and eclampsia] and there correlation with disease severity
}

\author{
Dr.Arnab Koley ${ }^{1}$, Dr.Swapan Das ${ }^{2}$, Dr. Sanjay Sarkar², Dr.Debashish Char ${ }^{2}$, \\ Dr.Tushar Kanti Saha ${ }^{3}$ \\ 1(PGT, B.S. Medical College, Bankura, India); 2(RMO, B.S. Medical College, Bankura, India); 3(Asst. Prof., \\ NRS Medical College, Kolkata, India)
}

\begin{abstract}
Background: Hypertensive disorders are the most common medical complications during pregnancy and are associated with high maternal and fetal mortality and morbidity. One way to reduce the impact of arterial hypertension on maternal mortality is to establish the correct diagnosis of preeclampsia, and to proceed with an early intervention when it is diagnosed. The clinical signs are considered to be a late manifestation of a disease. The utility of two biochemical markers like hyperuricemia and hypocalcemia for the diagnostic purposes and for the prognosis remains largely to be explored.
\end{abstract}

Objectives: [1] To determine the role of calcium \& uric acid in the pathogenesis of preeclampsia. [2] To determine the serum level of calcium and uric acid \& its correlation with the severity with preeclampsia.

Study Design: Hospital based cross sectional case control study.

Methods: The study was conducted in the Ante Natal Ward in Obstetrics \&Gynaecology Department, BankuraSammilani Medical College, Bankura, WB, which serves a rural population where majority of the patients belong to the tribal groups. Mild pre eclamptic patient defined as blood pressure of at least $140 / 90 \mathrm{~mm}$ of $\mathrm{Hg}$. at least on two occasions at least $6 \mathrm{hrs}$ apart accompanied by proteinuria of at least $300 \mathrm{mg}$ per $24 \mathrm{hrs}$ or at least $1+$ on dipstick testing. ${ }^{64}$

Severe preeclamptic patient defined as having one or more criteria of the following-

- $\quad B P \geq 160 / 110 \mathrm{~mm}$ of $\mathrm{Hg}$ at least on two occasions at least 6 hrs apart

- Proteinuria of $\geq 5 \mathrm{gm} / 24 \mathrm{hrs}$ or at least $3+$ on dipstick testing

- Oliguria $<500 \mathrm{ml} / 24 \mathrm{hrs}$ or Cerebral or visual disturbances or Pulmonary edema or any other features of end organ damage.

Statistical Analysis: Student's t test, Chi square test and statistical software Medcalc 11.3.0, Q1 Macros 2012. Results: There were no statistical significant difference in age, BMI, or birth weight of the baby between normal pregnant women and women with PIH but preeclamptic patients present early in gestational age and that was statistically significant. The serum calcium level in eclampsia and severe pre-eclampsia were significantly less than normal pregnant woman but there was no significant difference in serum calcium between normal pregnant woman and mild pre-eclamptic woman. The serum uric acid level in eclamptic woman and severe preeclamptic woman were significantly more than that of normal pregnant woman but there was no significant difference in serum uric acid between noral pregnant woman and mild pre-eclamptic woman.

Conclusion: So the study indicates that hyperuricemia and Hypocalcaemia is significantly associated with Preeclampsia and their level varies with the severity of the disease process. Routine estimation of serum uric acid and calcium level may be useful as diagnostic marker in high risk pregnancies.

Keywords: preeclampsia, eclampsia, serum uric acid, serum calcium.

\section{Introduction}

Preeclampsia/eclampsia has been called the "disease of theories." Itis defined as hypertension $(\mathrm{BP} \geq 140 / 90 \mathrm{~mm}$ of $\mathrm{Hg})$ and proteinuria $(\geq 300 \mathrm{mg} / 24 \mathrm{hr}$ ) occurring after 20 weeks of gestation in a previously normotensive woman. Although it is a relatively common entity and has been the subject of a large body of research, the search for an inciting agent and a unifying pathophysiological mechanism has generated more questions than answer ${ }^{1}$. In modern obstetrics, hypertensive disorders of pregnancy are understood to encompass a clinical spectrum of abnormalities ranging from minimal elevations in B.P to severe hypertension with multiorgan dysfunction ${ }^{2}$. Hypertensive disorders are the most common medical complications during pregnancy and are associated with high maternofetal mortality and morbidity. Collectively, these disorders complicate 5$10 \%$ of all pregnancies ${ }^{3}$.

One way to reduce the impact of arterial hypertension on maternal mortality is to establish the correct diagnosis of preeclampsia, and to proceed with an early intervention when it is diagnosed. The clinical signs are considered to be a late manifestation of a disease that has been present since the first trimester of gestation. Due 
to this "diagnostic delay", many tests have attempted to establish the diagnosis of preeclampsia as early as possible, often even before the patient presents arterial hypertension. Tests reported for the early diagnosis of preeclampsia are Doppler ultrasound assessment of maternal and fetal circulation, uric acid concentration, the supine pressure test, microalbuminuria, serum calcium and other tests, all of which are of debatable efficacy and practicality ${ }^{4}$.

The results from many clinical studies show the relationship between the aggravation of the hypertensive complications and the change in concentration of various chemistries in mother's serum ${ }^{5}$. Interestingly variable serum calcium and uric acid are found in pre eclamptic mothers ${ }^{6-8}$. Therefore the modification of calcium \& uric acid metabolism during pregnancy could be one of the potential causes of preeclampsia ${ }^{8}$. In this context, this study is aimed to measure the serum calcium and uric acid level in both normotensive and preeclamptic mothers and compare them.

\section{Materials And Methods}

This hospital-based, cross-sectional study was conducted at the Ante Natal Ward in Obstetrics \&Gynaecology Department, Bankura Sammilani Medical College, Bankura, WB.. The study was carried out from : $1^{\text {st }}$ JULY,2011 to 30th JUNE,2012, the cases being Mild \& severe pre eclampticand eclampsiapatients. Controls were normotensivepregnant women who were admitted for delivery. In each group there are 100 patients. All the participants had 28 or more weeks of pregnancy.

Mild pre eclamptic patient defined as blood pressure of at least 140/90 mm of $\mathrm{Hg}$. at least on two occasions at least $6 \mathrm{hrs}$ apart accompanied by proteinuria of at least $300 \mathrm{mg}$ per $24 \mathrm{hrs}$ or at least $1+$ on dipstick testing. ${ }^{9}$

Severe preeclamptic patient defined as having one or more criteria of the following-

- $\quad \mathrm{BP} \geq 160 / 110 \mathrm{~mm}$ of $\mathrm{Hg}$ at least on two occasions at least $6 \mathrm{hrs}$ apart

- Proteinuria of $\geq 5 \mathrm{gm} / 24 \mathrm{hrs}$ or at least $3+$ on dipstick testing

- Oliguria $<500 \mathrm{ml} / 24 \mathrm{hrs}$

- Cerebral or visual disturbances

- Pulmonary edema

- Epigastric or right upper quadrant pain

- Impaired liver function test

- Thrombocytopenia

- Foetal growth restriction ${ }^{9}$.

Patients with history of chronic hypertension, renal disease or cardiovascular disease, Thyrotoxicosis, Diabetes Mellitus and multiple gestations are excluded from the study.

Patientswere screened with complete history \& physical examination to determine their eligibility for inclusion in the study. On admission, venous serum samples were collected from the patient's antecubital vein with the patient in supine position,prior to their commencement of intravenous therapy . At the time of blood collection, urine samples were collected for protein estimation. Urine protein was measured by dipstick and graded on a scale of Trace to $4+($ Trace, $0.1 \mathrm{gm} / \mathrm{L} ; 1+, 0.3 \mathrm{gm} / \mathrm{L} ; 2+, 1 \mathrm{gm} / \mathrm{L} ; 3+, 3.0 \mathrm{gm} / \mathrm{L} ; 4+, 10 \mathrm{gm} / \mathrm{L})$.

Blood samples obtained on admission were sent for complete blood count, serum calcium and uric acid. . Serum uric acid was measured by enzymatic color test using Uricase and Peroxidase enzyme. The kit used is INFINITE URIC ACID Kit by Accurex, India. Expected normal values for Male: $3.4-7.0 \mathrm{mg} \%$ and Female: $2.4-5.7 \mathrm{mg} \%$. Serum calcium was measured by photometric color test by CRESOLPHTHALEIN COMPLEXONE METHOD using kits from SIEMENS. Reference value $8.5-10.5 \mathrm{mg} / \mathrm{dl}$.

Finally, data were analyzed with the help of basic statistical method like Student's t test,Chi square test and statistical software Medcalc 11.3.0, Q1 Macros 2012.

\section{Results and Analysis}

The present study enrolled 100 women with normal pregnancy and 100 pregnant women with pregnancy induced hypertension and both groups were 28 or more weeks of gestation. The clinical characteristics of the participants are shown in Table -1 . There was no significant difference in BMI between normal pregnant woman and pre-eclamptic woman $\left(23.39 \pm 1.24 \mathrm{~kg} / \mathrm{m}^{2}\right.$ versus $\left.23.97 \pm 1.72 \mathrm{~kg} / \mathrm{m}^{2}\right)$. In this study it was found that baby's birth weight of pre-eclamptic mother was less than that of normal pregnant woman $(2.39 \pm 0.45 \mathrm{~kg}$ vs $2.59 \pm 0.27 \mathrm{~kg})$ but the difference is not statistically significant [ pvalue $>0.05]$. It was found that mean gestational age in normal pregnancy was $37.38 \pm 1.26$ weeks and in pre-eclamptic mothers it was $36.22 \pm 1.55$ weeks. This difference is statistically significant ( $p$ value $<0.05 \quad$ ).

In Table -2 the serum calcium level in eclampsia and severe pre-eclampsia were significantly less than normal pregnant woman $(7.06 \pm 0.16 \mathrm{mg} / \mathrm{dl}$ and $7.22 \pm 0.41 \mathrm{mg} / \mathrm{dl}$ vs $8.81 \pm 0.59 \mathrm{mg} / \mathrm{dl}$ respectively (p value $<0.05$ ). But there was no significant difference in serum calcium between normal pregnant woman and mild preeclamptic woman $(8.81 \pm 0.59 \mathrm{mg} / \mathrm{dl}$ vs $8.5 \pm 0.51 \mathrm{mg} / \mathrm{dl}$, (p value $<0.05)$. 
The serum uric acid level in eclamptic woman and severe pre-eclamptic woman were significantly more than that of normal pregnant woman $(7.07 \pm 0.22 \mathrm{mg} / \mathrm{dl}$ and $7.04 \pm 0.17 \mathrm{mg} / \mathrm{dl}$ vs $4.48 \pm 0.76 \mathrm{mg} / \mathrm{dl}$ respectively, $(\mathrm{p}$ value $<0.05$ ). There was no significant difference in serum uric acid between noral pregnant woman and mild pre-eclamptic woman $(4.48 \pm 0.76 \mathrm{mg} / \mathrm{dl}$ vs $5.05 \pm 1 \mathrm{mg} / \mathrm{dl}$, (p value $<0.05)$.

\section{Discussion}

In this study serum calcium and uric acid levels in healthy pregnant woman and hypertensive pregnant woman were measured and compared. In our study it was found that the serum calcium level in eclampsia and severe pre-eclampsia was significantly less than normal pregnant woman. But there was no significant difference in serum calcium level between normal pregnant woman and mild pre-eclamptic woman. Malas N.O. et.al ${ }^{10}$, Mohieldein A H et.al ${ }^{11}$,Chaurasia P.P et.al ${ }^{12}$, Li W et.al ${ }^{13}$ all found reduced serum calcium in preeclamptic mother's with comparison to normal pregnant mothers. But S. Golmohammad Lou et.a ${ }^{14}$ conducted study on trace elements in blood in pre-eclampsia showed that there was no significant difference in serum concentration of calcium between the patients with pre-eclampsia and normotensive controls. Mohieldein AH et.al ${ }^{11}$ stated in the study that low level of maternal total calcium may have a roll in the development of pregnancy induced hypertension. Therefore, calcium consumption in pregnancy should be encouraged and recommended calcium supplement for women who live in places of low socio economic status as well as for women who prefer to skip milk and milk products due to personal preferences. In our study it was found that the serum uric acid level in eclamptic mothers and severe pre-eclamptic mothers were significantly more than normal pregnant woman but there was no significant difference in serum uric acid level between normal pregnant women and mild pre-eclamptic women. Shah C J et.al ${ }^{15}$ stated that serum uric acid levels are significantly raised in pre eclampsia than normal pregnancy and there is a high positive correlation with the disease severity in relation to hypertension and proteinuria. Lim KHet $\mathrm{al}^{16}$ also emphasised the clinical utility of serum uric acid measurements in hypertensive diseases of pregnancy. That elevated concentration of serum uric acid in pre-eclamptic women is not simply a marker of diseases severity but rather contributes directly to pathogenesis of the disease was shown by SA Bainbridge et.al ${ }^{17}$. Hyperuricemia correlates closely with plasma hydrogen peroxide and protein carbonyl levels in preeclampsia and therefore serves an indicator of the underline oxidative stress of pre-eclampsia which was proved by Kiyomi T et.al ${ }^{18}$. But Crossen J S et.al ${ }^{19}$ concludes there is currently insufficient evidence to draw firm conclusions about the accuracy of serum uric acid determination in predicting preeclampsia. Hickman P.E et.al ${ }^{20}$ concluded from their study that serum uric acid is an unreliable indicator of developing hypertension in the individual woman. However, a rapidly rising uric acid level should be viewed with caution.

The present study showed that serum calcium in severe preeclampsia was lowered and serum uric acid was higher than normal pregnant and mild preeclamptic woman respectively. But there were no differences between normal pregnant woman and mild pregnant woman. This findings support that hypocalcaemia and hyperuricaemia correlates to severe preeclampsia.

Considering high prevalence of preeclampsia in our country and especially in our study area special attention to nutritional condition of pregnant woman seems warranted and also educating pregnant woman about nutrition during pregnancy and informing them about probable risk of inappropriate diet.

\section{Conclusion}

So, from our study we can conclude that there is Hyperuricemia and Hypocalcaemia is significantly associate with Preeclampsia and their level varies with the severity of the disease process . Routine estimation of serum uric acid and calcium level may be useful as diagnostic marker in high risk pregnancies and these levels may have a cause and effect relationship with these disorders and these data may therefore be found useful when considering interventional management of preeclampsia and eclampsia using calcium supplementation.

\section{References}

[1]. Darnforth editor Obstetrics \& Gynecology (1999), Lippincott Williams and Wilkins, New York, 309-327.

[2]. Cunningham FG, MacDonald PC \& Gant NF (1989). Hypertensive disorders in pregnancy. In: Cunningham FG, MacDonald PC \& Gant NF (Editors), Williams Obstetrics. Prentice-Hall, Norwalk, 653-694.

[3]. Andrea G. Witlin, and Sibai B M. Hypertension in pregnancy: current conceptsof preeclampsia. Ann Rev Med 1997 Feb; 48 : 115127.

[4]. J.G.L. Ramos, S.H. Martins-Costa, J.B. Kessler, C.A. Costa and E. Barros. 1HCalciuria and preeclampsia.Braz J Med Biol Res, 1998, 31(4) 519-522

[5]. Walker JJ.Preeclamsia.Lancet 2000;356:1260-5.

[6]. Ray J, Vasishta K, Kaur S, Majumdar S, SawhneyH. Calcium metabolism in pre-eclampsia.Int J GynaecolObstet 1999; 66: 245-50.

[7]. Kisters K, Korner J, Louwen F, Witteler R, JackischC, Zidek W, et al. Plasma and membrane Ca2+ andMg2+ concentrations in normal pregnancy andin preeclampsia. GynecolObstet Invest 1998; 46:158-63.

[8]. Singh J, O’Donovan M, Coulter-Smith SD, GearyM. An audit of the use of magnesium sulphate in severe pre-eclampsia and eclampsia. J ObstetGynaecol 2005; 25: 15-7 
[9]. ACOG practice bulletin.Diagnosis and management of pre eclampsia and eclampsia.No.33,January 2002.ObstetGynecol2002;99;159-67.

[10]. MalasoNO,ShuridehZM.Serum calcium in Pre eclampsia and normal pregnancy.Saudi Med J.2001 Oct ;22(10):868-71.

[11]. MohieldeinAH.Serum Calcium in Pre eclampsia.SudanJoural of Medical Sciences; Vol 2,No 4(2007).

[12]. 12.Pallavi P Chaurasia.Serum calcium in Pre eclampsia.doi:107439/ijbar.V3i6.508

[13]. Qi Q, Li W, Wang Z. Serum Calcium in Pathophysiology of Pre eclampsia.Zhonghua Fu Chan KaZaZhi 1997 Jan;32 (1):15-8.

[14]. S.Golmohammedlou,AAmirabi, M.Yazdian,N.Pashapour. Evaluation of serum Calcium, Magnesium,copper,Zinc levels in women with Pre eclampsia. IJMS 2008 Dec No. 4; vol 33:231-4.

[15]. Shah CJ.serum uric acid levels in PIH. Int. J.Med.Public health,2011;1(1):39-42

[16]. Lim KH, Friedman SA, Ecker JL, Kao L and. Kilpatrick SJ. The clinical utility of serum uric acid measurements in hypertensive diseases of pregnancy. Am J Obstet Gynecol. 1998 May;178(5):1067-71.

[17]. SA.Bainbridge,JMRoberts.Placentavol 29, supplement 1,March 2008:67-72.

[18]. KiyomiTsukimori of Kyushu University,Japan.American Journal of Hypertension 2008;21,12:1343-1346.

[19]. Cnossen JS, de Ruyter-Hanhijarvi H, van der Post JA, Mol BW, Khan KS, terRiet G. Accuracy of serum uric acid determination in predicting pre-eclampsia:a systematic review. ActaObstetGynecolScand 2006; 85(5):519-25.

[20]. Hickman PE, Michael CA, Potter JM.Serum uric acid in hypertension in Pregnancy.Aust NZ J Obst Gynecol.1982 NOV ;22(4):198-202.

TABLE - 1

Comparison of Clinical characteristics for the two groups of participants.

\begin{tabular}{|l|c|c|}
\hline Clinical Characteristics & Normal Pregnancy & Pre- eclampsia. \\
\hline Age (Yrs) & $20.95 \pm 1.24$ & $20 \pm 1.29$ \\
\hline Gestational age (Weeks) & $37.38 \pm 1.26$ & $36.22 \pm 1.55$ \\
\hline BMI $\left(\mathrm{Kg} / \mathrm{m}^{2}\right)$ & $23.39 \pm 1.24$ & $23.97 \pm 1.72$ \\
\hline Birth weight $(\mathrm{kg})$ & $2.59 \pm 0.27$ & $2.39 \pm 0.45$ \\
\hline
\end{tabular}

TABLE - 2

Comparison of Serum Calcium and Uric acid level for normal pregnancy, mild pre-eclampsia, severe preeclampsia and eclampsia.

\begin{tabular}{|l|l|l|l|l|}
\hline $\begin{array}{l}\text { Serum Level (mg / } \\
\text { dl) }\end{array}$ & \multicolumn{1}{|c|}{ Normal pregnancy } & $\begin{array}{c}\text { Mild } \\
\text { pre-eclampsia }\end{array}$ & $\begin{array}{c}\text { Severe } \\
\text { pre-eclampsia }\end{array}$ & Eclampsia \\
\hline Serum calcium & $8.81 \pm 0.59$ & $8.5 \pm 0.51$ & $7.22 \pm 0.41$ & $7.06 \pm 0.16$ \\
\hline Serum uric acid & $4.48 \pm 0.76$ & $5.05 \pm 1.00$ & $7.04 \pm 0.17$ & $7.07 \pm 0.22$ \\
\hline
\end{tabular}

